Where's the action in endocrinology?

\author{
J. R. Tata
}

Hormones. By Anthony W. Norman and Gerald Litwack. Academic: 1987. Pp.806. $\$ 49.95$, $\$ 37$.

Hormones are big business for publishers, but useful, unconventional textbooks of modern endocrinology are few and far between. The hopes for something new in Norman and Litwack's Hormones are partially fulfilled. According to the authors, the book "provides a comprehensive treatment of human hormones" for first-year medical students, graduate students and advanced undergraduates in the biological sciences. Only parts of it can be said to be truly useful for this group of readers, but the book does succeed in fulfilling the authors' claim to "filling a void" in its emphasis on the cellular and molecular aspects of the subject.

Except for chapters on "general considerations", steroid hormones and growth factors, the 16 chapters constituting the bulk of the book deal with hormones according to which gland makes them. This is the traditional approach and it results in considerable repetition of topics such as mechanism of action of hormones, receptors and multi-hormone systems. Had the authors divided much of the material into individual accounts of general issues - hormones and second messengers, nuclear receptors and gene structure and function, membrane receptors and phosphorylation, co-evolution of peptide hormones and their receptors, feedback mechanisms and the integration of neural and endocrine systems, for example - not only would they have avoided such repetitiveness but they would have provided a much-needed consideration of hormones as part of a continuously evolving system of biological regulation via chemical signals.

For first-year medical students, the descriptions of anatomy of endocrine glands, physiological actions of hormones and clinical manifestations of endocrine disorders will certainly be helpful. But one may well ask of what value are the numerous diagrams of protein and DNA sequences of peptide hormones, receptors and their genes for students of medicine or general biology? Norman and Litwack say that this is to impress the reader of the recent rapid progress in molecular biology, particularly in recombinant DNA and gene cloning. Couldn't this have been said in a few sentences? Although giving the book a cachet of trendiness, the exaggerated emphasis on these new technologies makes it less definitive and more likely to date quickly. Quite rightly, the authors have stressed the cellular and molecular basis of hormone action, but they fail to emphasize that this is simply a reflection of what we know at a given time about biochemical, cellular and molecular mechanisms of biological regulation as a whole.

The material is well presented with clear illustrations (the anatomical diagrams of endocrine glands and the portrayals of biosynthetic and metabolic pathways of hormones are particularly good). Many of the models of hormone action are reminiscent of those in Biochemical Actions of Hormones, the highly successful series edited by Litwack; some, though, need revision. I could spot only few errors such as cyclic AMP being described as a hormone on p.40. The bibliography, listing review articles and research papers separately, is remarkably

up to date, although one frequently notices omissions of references to pioneering work. There is also an informative appendix at the end, with a compilation of the sites of synthesis and actions of the major mammalian hormones, their concentration in blood and diseases associated with them, but the inclusion of a list of Nobel laureates is puzzling.

All things considered, Norman and Litwack's Hormones will find an appreciative audience of first-year medical students and undergraduates reading biology. It will also serve as a good source book for cellular and molecular endocrinologists - at least for the next five to ten years.

J.R. Tata is Head of the Laboratory of Developmental Biochemistry at the Medical Research Council National Institute for Medical Research, Mill Hill, London NW7 $I A A, U K$.

\section{Enigmatic reprise}

\section{Alan Nunn May}

Klaus Fuchs, Atom Spy. By Robert Chadwell Williams. Harvard University Press: 1987. Pp.267. \$25. To be published in Britain on 23 November, $£ 19.95$.

ANOTHER biography of Klaus Fuchs so soon after Norman Moss's (reviewed here on 4 June $^{*}$ ) may seem too much of a good thing, but there are interesting contrasts in the two treatments. As a journalist, Norman Moss based his account largely on interviews. Professor Williams, a historian, uses mainly documents, among them the papers of Chadwick, Cockcroft, Peierls, Cherwell, the memoirs of Jurgen Kuczinski (Fuchs's first contact) and the FBI papers on the case, which include MI5 documents which are still secret in Britain. For the first time we can read Fuchs's full technical confession, and Harry Gold's confession to the FBI.

All this yields many new insights. But at times Professor Williams is tempted rather far from his main topic, and he does not always achieve complete accuracy. To give three examples of errors among many, he says that Britain and the Soviet Union were still enemies during the first six months of 1941; that Max Born's laboratory in Göttingen was one of the great centres of nuclear physics; and that the cyclotron used alternating magnetic fields to accelerate particles.

On the other hand, Professor Williams's explanation of the English law of treason, and why Fuchs was not charged with this crime, but only with the offences under the Official Secrets Act, clarifies a topic much confused by previous writers, including Norman Moss. He is also the first to mention the secret Anglo-Russian agreement, promising full exchange of information on all new weapons, which has been glossed over or ignored by atomic historians. But the suggestion that therefore Fuchs was only helping the British to fulfil their treaty obligations would probably have failed to impress the judge at his trial.

About the trial Professor Williams holds strong opinions. He says that there should have been a jury, with witnesses and cross-examination. He holds that the British prevented this to avoid some embarrassing disclosures, such as Fuchs's role in the secret British bomb project; the Russian penetration of MI5 and MI6; the (official) sharing of intelligence with the Russians during the war, and contacts between Jurgen Kuczinski and cabinet ministers. The first of these points might have had some influence, but the others were either unknown at the time, or were barely relevant to the Fuchs case. One must exonerate the British of perverting justice. There was no jury because a plea of guilty leaves nothing for a jury to do.

It is a pity that Norman Moss and Professor Williams did not collaborate and produce a joint work. Moss's personal contacts, Professor Williams's documentation and a mutual correction of errors could have produced the definitive biography.

Alan Nunn May was a member of the BritishCanadian atomic project in Montreal from 1943 to 1945 . In 1946 he was convicted of passing information to the Soviet Union, and was sentenced to ten years in prison. In 1961 he was appointed Professor of Physics in the University of Ghana, and retired in 1978.

*Moss's book (Klaus Fuchs: the Man Who Stole the Atom Bomb), which was published earlier this year in Britain by Grafton, becomes available in the United States on 2 November. Publisher is St Martin's, price is $\$ 15.95$. 